\title{
Lys-63-Specific Deubiquitinase BRCC36
}

National Cancer Institute

\section{Source}

National Cancer Institute. Lys-63-Specific Deubiquitinase BRCC36. NCI Thesaurus. Code C124111.

Lys-63-specific deubiquitinase BRCC36 (316 aa, $36 \mathrm{kDa}$ ) is encoded by the human $B R C C 3$ gene. This protein plays a role in DNA repair and the removal of ubiquitin from histones. 